\title{
Mixed-Method Research to Foster Energy Efficiency Investments by Small Private Landlords in Germany
}

\author{
Steven März ${ }^{1, * \mathbb{C}}$, Anja Bierwirth ${ }^{1}$ and Ralf Schüle ${ }^{2}$ \\ 1 Division: Energy, Transport, Climate Policy, Wuppertal Institute; Döppersberg 19, \\ 42103 Wuppertal, Germany; anja.bierwirth@wupperinst.org \\ 2 Division: Digital Cities, Risk Prevention and Transportation, Federal Institute for Research on Building, \\ Urban Affairs and Spatial Development (BBSR), Deichmanns Aue 31-37, 53179 Bonn, Germany; \\ Ralf.Schuele@BBR.Bund.de \\ * Correspondence: steven.maerz@wupperinst.org; Tel.: +49-202-2492-295
}

Received: 4 February 2020; Accepted: 19 February 2020; Published: 25 February 2020

\begin{abstract}
The decarbonisation of the building stock is an important element for the success of the German Energiewende (energy transition). Despite some progress having been made, the rate of energy renovation falls below the level required to meet political commitments. This gives rise to the question: what deters property owners from making energy efficiency investments and how can the policy framework foster such investments? To answer this question, the paper focuses on a widely neglected property owner group: small private landlords (SPL). Although they manage $37 \%$ of all residential rental properties in Germany, very little is known about their decision-making processes for energy efficiency investments. We applied a mixed-method design to identify factors that hindered and supported their investments. In an explorative study, we initially conducted 18 problem-centred interviews. Subsequently, we carried out a postal survey and analysed the questionnaires using a hierarchical linear regression model. The results show that energy renovation is a multi-dimensional decision-making process, which can only be adequately addressed by a comprehensive policy package. To develop such a package, the author recommends that the specific investment behaviour of SPL must be better targeted, their knowledge about energy efficiency investments must be improved through exchange and networking, a sense of responsibility for the neighbourhood must be fostered, and greater focus must be placed on improving local framework conditions.
\end{abstract}

Keywords: energy renovation; small private landlord; mixed-method; problem-centred interview; OLS regression; rental market; Germany; governance; building

\section{Introduction}

The latest IPCC report indicates that it may still be possible to limit global warming to between 1.5 and $2.0^{\circ} \mathrm{C}$, and, consequently, to stay within planetary boundaries [1]. However, the report also emphasises the tremendous efforts that will be necessary for a turnaround in global GHG emissions in the next couple of years [2]. The German national strategy to tackle climate change, the "German Energiewende", aims to reduce $\mathrm{CO}_{2}$ by $80 \%$ to $95 \%$ by 2050 compared to 1990 levels. The building sector has a crucial role to play in achieving this target because it causes one third of Germany's GHG emissions [3].

The German building sector has successfully reduced its $\mathrm{CO}_{2}$ emissions by $43 \%$ since 1990 [4], but in recent years this reduction has tailed off. The annual rate of energy renovations is still way below the necessary $2 \%$ to $3 \%[5,6]$. While investment volumes for general building retrofits and renovations have increased in the last 10 years, the absolute volume and relative share of energy efficiency investments have decreased [7]. Moreover, comprehensive renovation programmes have 
increasingly become the exception, with property owners instead investing in single measures to tap low-hanging fruits [8].

Investments in energy efficient buildings in Germany are currently not only insufficient for meeting climate protection targets but are also unevenly distributed among the various property owner groups. Properties owned by not-for-profit housing associations and, to some extent, owner-occupied homes experience higher renovation rates and energy efficiency performance than properties owned by private landlords $[5,6]$, which is in line with international evidence $[9,10]$.

This raises the question: what deters landlords from investing in energy efficiency? To answer this question, comprehensive knowledge about their decision-making processes is crucial. While much is known about homeowners in Germany [11-15] and abroad [16-19], as well as about professional landlords [20,21], very little is known about small private landlords (SPL) [22,23], despite the fact that they own $37 \%$ of all residential apartments in Germany. This is the starting point of the analysis, in which the authors used a mixed-method research design [24] to analyse the decision-making processes of SPL and identify the supportive and obstructive factors. The purpose of the paper is twofold. Firstly, it aims to shed light on the decision-making processes of a neglected actor in the German Energiewende, the small private landlord. Secondly, the findings should help to develop better-tailored policies for promoting energy efficiency investments, resulting in building stock with nearly-zero emissions.

\section{German Energiewende and the Role of Small Private Landlords (SPL)}

\subsection{German Policy Framework for Achieving a Nearly-Zero Emissions Building Stock}

Germany aims to reduce the primary energy demand of the building stock by $80 \%$ by 2050 compared to 2008 levels, to achieve building stock with nearly-zero emissions. The "building energy efficiency strategy" brings together different policies, ranging from regulation and incentives to research, information and consultancy [25].

Since 1977, mandatory minimum energy efficiency standards for new buildings have been in place. These have been tightened several times, reducing the energy demand of new buildings by approximately $50 \%[13,26]$. Further tightening is expected in line with the EU Energy performance building directive (EPBD), which should lead to nearly-zero energy buildings by 2021. The so-called "Modernisierungsumlage" ( $\$ 559$ BGB) in tenancy law provides an incentive for landlords to invest in energy efficiency by allowing landlords to pass on $8 \%$ of all energy-related costs to their tenants, meaning that energy efficiency investment has a payback period of 12.5 years.

The " $\mathrm{CO}_{2}$ buildings rehabilitation programme" offers subsidised loans and grants for comprehensive energy refurbishments to achieve 'KfW Efficiency House' standards, as well as for individual energy efficiency measures in existing buildings [27]. Landlords only benefit from subsidised loans, while homeowners can choose between grants and loans (including a repayment bonus). Funding rates depend on the building's energy efficiency performance after the renovation. For example, at the time of writing (01.02.2020), landlords who renovate their rental properties towards "KfW Efficiency House Standard 55", meaning the building requires only 55\% compared to the minimum energy performance standard, defined in the German Energy saving Ordinance (EnEV), are rewarded with low interest rates and a repayment bonus of $40 \%$, while for a single measures only $20 \%$ bonuses are available. Under the German tax system, energy efficiency investments are also tax deductible.

In addition, the German government provides information, advertising campaigns such as "Dämmen lohnt sich" ("insulation is worthwhile"), and different forms of energy consultancy to raise awareness and acceptance of the ecological necessity and the economic benefits of energy efficiency investments.

Despite this comprehensive framework, which has led the International Energy Agency (IEA) to conclude that "Germany is among the world leaders in terms of energy-efficient buildings" [28], 
an energy efficiency gap exists and Germany is expected to miss its short-term and long-term energy efficiency targets. The rate of energy refurbishment remains low, at approximately $1 \%$ per year [5], which is far lower than the $2 \%$ to $3 \%$ needed. In addition, investments in energy efficiency have decreased in recent years, although overall investments in building renovations have increased [7]. This raises the question of whether the policy framework is still fit for purpose for reaching the aim of building stock with nearly-zero emissions and for targeting the specific needs of property owners. To answer this question, we must take a closer look at the different property owner types and their investment behaviour.

\subsection{The Role of Small Private Landlords in Achieving a Nearly-Zero Emissions Building Stock}

The owner structure of the German residential building market is heterogeneous. Only $20 \%$ of apartments are owned by professional housing companies. The rest are owned and managed by homeowners $(43 \%)$ and small private landlords (37\%). The proportion of rental properties owned by SPL underlines the fact that their investment in energy efficient measures is crucial for achieving building stock with nearly-zero emissions.

The little available data and studies about SPL emphasise two points. Firstly, the level of energy efficiency investments by this owner group is lower than for other groups. Secondly, policies are not effective in targeting or motivating SPL. Michelsen et al. [29] analysed more than 100,000 energy efficiency certificates relating to multi-family buildings and concluded that professional landlords renovate more ambitiously than SPL due to economies of scale and scope. The total energy consumption of residential buildings managed by professional landlords decreases by $36 \%$ following comprehensive energy renovation, compared to a decrease of $18 \%$ for properties managed by SPL. This result is in line with the findings of Henger and Voigtländer [30]. They show that SPL invest more frequently, but at lower levels, than professional landlords. The average renovation spend by professional landlords is between $€ 347 / \mathrm{m} 2$ and $€ 560 / \mathrm{m} 2$, compared to $€ 277 / \mathrm{m} 2$ by SPL. The authors also show that SPL are less likely to increase their rents following energy renovations than professional landlords. If they do increase the rent, the rise is moderate (5\%) in comparison to the average rise made by professional landlords (25\% to $28.6 \%$ ). Cischinsky and Diefenbach [5] conducted a representative study for the different owner groups in Germany and the results highlighted the backlog of energy renovations in properties owned by SPL. Only 33\% of the facades of multi-family buildings owned by SPL have been insulated, compared to $47.5 \%$ in properties owned by professional landlords. This figure is even lower for communities of owners (17.1\%). Renz and Hacke [31] compared different determinants for energy renovation for homeowners and SPL. They concluded that homeowners renovate to a higher energy efficiency performance standard because they benefit from co-benefits such as comfort, lower heating costs, etc. In contrast, SPL tend to make investments to meet regulatory standards. Homeowner associations (HOA) are a particular type of ownership where a residential building is owned by different owners, primarily SPL and owner-occupied homes. Investment decisions require coordination to balance all the individual interests, with the result that the greatest backlog in energy efficiency investments is in buildings of this type of ownership [5,32].

These results are in line with international evidence. In England, the number of $F$ and $G$ rated properties, meaning the most energy inefficient buildings, fell at a slower rate in the private rented sector than for any other group of owners between 1996 and 2012, and in the private rented sector the share of $\mathrm{F}$ and $\mathrm{G}$ rated buildings is the highest [33]. Broberg and Egüez [34] emphasise the fact that energy efficiency performance in Swedish multi-family buildings is significantly higher for cooperative apartment associations than for private rental properties. In the US, $43 \%$ of private rented properties have double-glazing, compared to $63 \%$ of owner-occupied homes, with only $28 \%$ being considered "well-insulated" (compared to 40\%) [35]. In the Netherlands, private rentals also have lower levels of attic and wall insulation and efficient glazing (40\%, 29\% and $48 \%$, respectively) than owner-occupied buildings ( $70 \%, 52 \%$ and $70 \%)$ [36]. 
The existing studies show there is a backlog of energy renovations in residential rental properties, particularly those let by SPL. SPL even neglect economically viable energy efficiency investments, which underlines the need for policies designed to meet political targets to be tailored to the specific needs of SPL. It is clear that a more comprehensive understanding of the decision-making processes of SPL is required to fully exploit existing energy efficiency potentials.

\section{Mixed-Method Research Design}

We opted for a mixed-method design to understand the decision-making processes of SPL (see Figure 1) [24]. Mixed-method research designs are used to answer various disciplinary and inter-disciplinary research questions which are related to our topic, such as energy-related behavior [37] or affordable housing and tenant preferences [38], but also to other issues like gamification [39] or big data analytics [40]. Lopez-Fernandez and Molina-Azorin [41] provide an extended overview of the usage of a mixed-method research design in behavioral science. Qualitative and quantitative methods "should be mixed in a way that has complementary strengths and non-overlapping weaknesses" [42]. The aim of the triangulation is twofold. Firstly, it is anticipated that mixing will lead to results of greater validity than using only one method [43]. Qualitative data may help to interpret quantitative model results and quantitative results can verify or falsify explorative findings from qualitative research. Secondly, comparisons between qualitative and quantitative results may reveal further research needs.

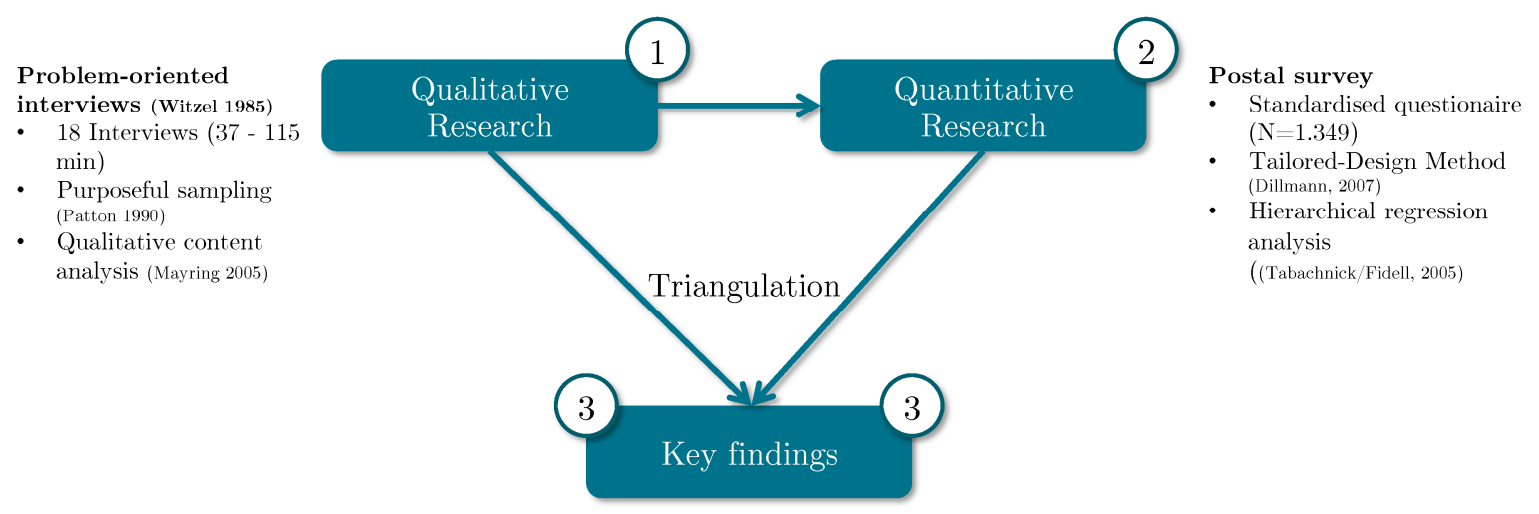

Figure 1. Summary of the mixed-method research design.

We used a sequential qualitative-quantitative mixed-method research design to investigate the decision-making processes of SPL [44]. Due to the current limited knowledge about SPL, a sequential approach was appropriate, as it allowed the explorative identification of supportive and obstructive factors (qualitative research), which could then be quantitatively evaluated in terms of their relevance/significance. A total of 18 interviews (ranging from 37 to $115 \mathrm{~min}$ each) were conducted and analysed using content analysis [45]. Interviews were conducted until a theoretical saturation was reached [46], although the number of interviews was in line with other qualitative research on building energy consumption [47]. The sampling was 'purposeful', aiming for maximum variation [48]. Therefore, both renovators and non-renovators were selected. The qualitative research led to an integrated decision-making model including four decision dimensions with 14 determinants affecting energy efficiency investments.

Subsequently, a postal survey was conducted in spring 2017 using the "tailored-design method" [49]. Participants were asked to complete a nine page questionnaire, which included socio-economic information, information about their rental properties in the neighbourhood and measures to understand the significance of 14 determinants. A total of 351 SPL participated in the survey ( $26 \%$ response rate). The results are based on 190 completed questionnaires. The survey was analysed using a hierarchical OLS regression model [50]. In contrast to an ordinary least square (OLS) regression, where all independent variables are included in the model at once, in hierarchical OLS 
regression independent variables enter the equation in an order specified by the researcher, which allows for the assessment of the added value of the different dimensions and determinants in the decision-making process.

The author conducted the qualitative and quantitative research activities in a small inner-city neighbourhood in Oberhausen. Oberhausen is a city in the Ruhr area of Germany with approximately 212,000 inhabitants. The city and neighbourhood are closely linked to the rise of the coal and steel industries at the end of the 19th century and their decline from the 1960s onwards [22,51]. The decline led to enormous socio-economic challenges for the city [52,53]. The city has lost more than 50,000 inhabitants in the last half century and has one of the highest levels of debt per capita in Germany [54]. Consequently, the case study represents neighbourhoods suffering from high vacancy rates, low rents and a high share of low-income households, with a heterogeneous building ownership structure and buildings mainly constructed prior to, or during the early decades of, the 20th century. Such neighbourhoods exist in other parts of Germany, such as in Saarland, Bremen, parts of former East Germany and other cities in the Ruhr area, as well as, in all likelihood, in other European neighbourhoods faced with economic structural change.

\section{Results from the Qualitative Research}

Decision-making is a complex process. Consequently, several research disciplines have developed different approaches to understand why and how individuals decide for or against an alternative. Instead of disciplinary approaches, Stern [55] argues that integrated and holistic approaches are required to fully understand individual decision-making. He identities the following four dimensions of a decision-making process: (pro-environmental) attitude, habits, personal capabilities and external factors. We applied these four dimensions to our case study.

The interviews showed that investment decisions are made by SPL in a two-step process. Firstly, there must be a reason for an SPL making an investment. Reasons include the need for a repair, the leaving of a tenant, a complaint made by a tenant and the desire to preserve the value of the property or to make improvements. In the second step, the above-mentioned dimensions determine whether an SPL invests or not and whether the investment will be a standard solution (e.g., painting a wall) or an energy efficiency solution (e.g., wall insulation). The second step, therefore, influences energy efficiency investments and requires deeper understanding to ensure that existing energy efficiency potentials are exploited. A total of 14 determinants were identified based on the interviews and a comprehensive literature review, and these were each assigned to one of the four dimensions (see Figure 2). A brief overviews follows and more detailed results are presented by März [50].

\section{1. (Pro-Environmental) Attitude}

Interviewees showed broad support for the "German Energiewende". Most are aware of the scarcity of fossil fuels and agreed that new ways of energy generation and conservation are required (environmental awareness). However, this awareness did not automatically lead to environmentally friendly behaviour (revealing a value-action gap) [56], as hardly any of the interviewees took personal responsibility or felt morally obliged to change their behaviour (personal norm).

'Why should I do that? Because I'm an environmentalist? Germany is a small country and Merkel made it her priority to be a role model. This is ridiculous. As long as we support the lignite industry, what does she want from us private homeowners?' (IP 5:112) 


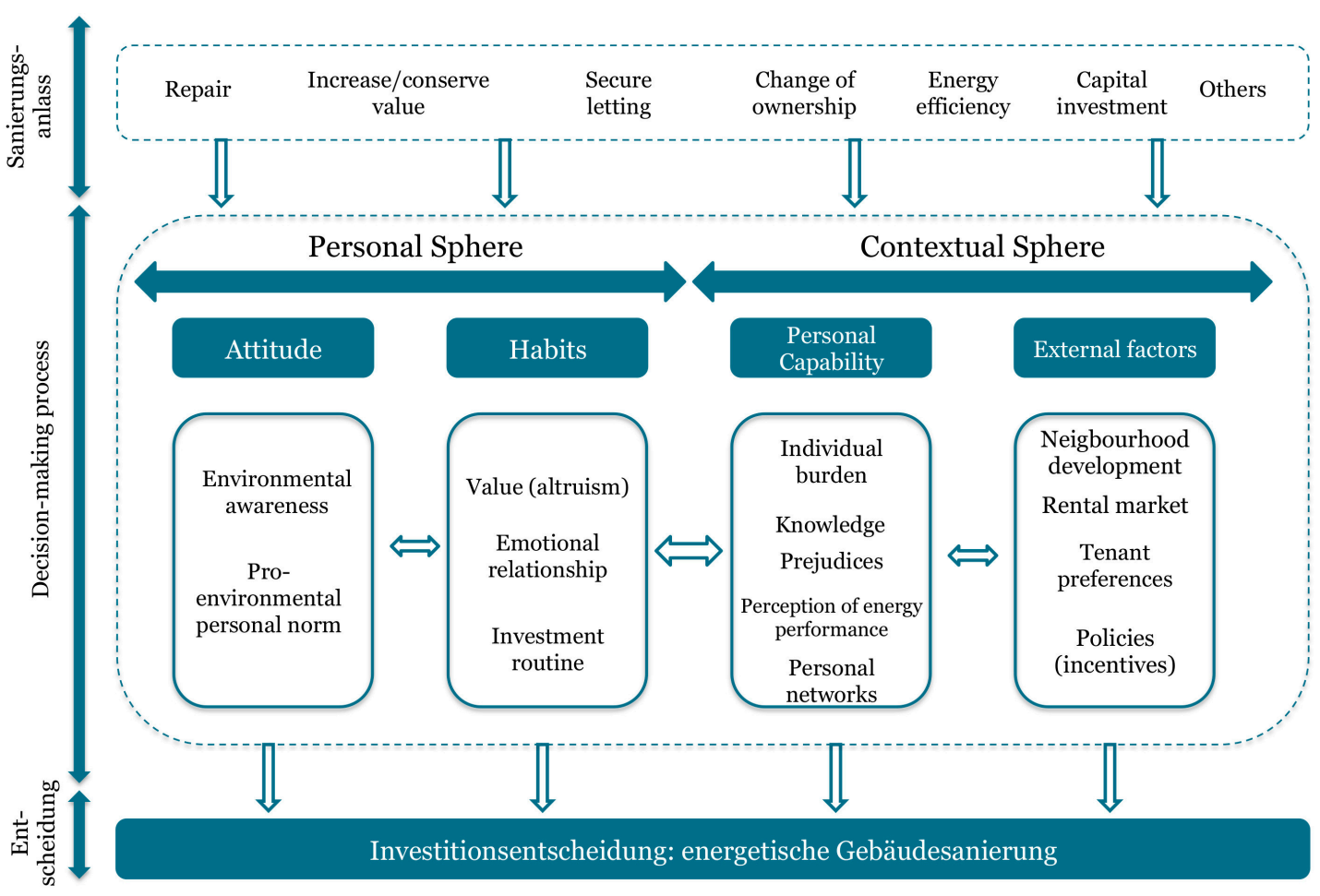

Figure 2. Integrated decision-making model.

\subsection{Habits}

Most of the interviewees showed a more altruistic attitude (value) than expected. Their priority in terms of rental management is not to maximise return but to operate well-run and hassle-free tenancies.

'I belong to those, who not believe to earn treasures from letting ( . . ) My attitude is a social one.

(... ) I do not belong to those, who say I have to get as much as possible out of it.' (IP 12: 110-114)

In particular, SPL who had inherited their buildings or flats, who had owned them for decades or had grown up in the neighbourhood stated that they invest in their buildings to stop the downwards trend of the neighbourhood, because they identify with the neighbourhood and/or the building (emotional relationship).

'My heart goes out to this house and it hurts to see this neighbourhood deteriorating if nobody invests. This is also why I do invest' (IP 3:60)

The interviews revealed that the typical SPL approach to investment does not lend itself to large energy efficiency investments. SPL are conservative and tend to be risk-averse in their investment behaviour. They reject loans and prefer an ongoing investment programme, in which they save up to finance an investment and then start saving again. They do not generally have an investment strategy; instead they invest on demand (e.g., repairs) and their investments follow a certain hierarchy, in which energy efficiency is at the bottom level (investment routine).

I'm not somebody who buys things I cannot afford. With the incoming rents I pay my bank and the rest is saved until I have to money to just buy the new door' (IP 4: 85)

\subsection{Personal Capabilities}

Financial or time constraints, combined with the management burden of investment planning and supervision (individual burden), are obstacles for energy efficiency investment and become more relevant with the increasing age of SPL. 
'You know what, the government wants us to take care of our pension savings. This house is supposed to pay for the care service or even the care home for my mother. You can only spend each Euro once' (IP 1b, postscript)

Knowledge about energy efficiency is heterogeneous within the target group and unclear in terms of its effect. It can reduce prejudice, but confirmation bias can also play a role. Prejudice is widespread and includes issues such as mould, fire risks, hazardous waste, aesthetics and doubts about ecological and financial meaningfulness.

'So, I wouldn't rip out the windows because that would damage the façade. If we had completely airtight windows, I would have a mould problem because of the way they [the tenants] use the heating. They tilt the window and when they close it, the humidity remains inside. And so I'd rather keep the windows the way they are. They are from the 80 s and already double-glazed' (IP 4)

Personal networks are theoretically seen as a means of innovation diffusion. However, the existence of such networks for exchanging information and experience is rare within the target group and their effect can be negative as well as positive.

Many interviewees overestimated the energy efficiency performance of their rental buildings and underestimated their energy efficiency potentials (perception of the buildings energy efficiency performance).

The energy efficiency performance is not bad. I have an energy efficiency certificate. The value is around 160. This is quite ok for a building of the 1960s. To realise a KfW efficiency house standard/This is impossible with such an old building because of the architectural circumstances. (IP 6: 35)

\subsection{External Factors}

The neighbourhood has undergone tremendous structural changes. These changes negatively affected its image and reduced the quality of existing technical and social infrastructures, etc., all of which reduces the desirability of investing (neighbourhood development).

When you talk to the old people, they all tell you it has become colossal worse than 20-30 years ago. That's true! (IP 16: 67)

The way in which the neighbourhood has developed impacts strongly on the rental market. High vacancy rates and low and stagnant rents make energy efficiency investments economically unviable and risky for SPL as they cannot pass the cost onto tenants.

'Yes, you can increase the rent. Then you have a higher rent but an empty apartment' (IP 2)

Moreover, the tenant structure itself-with lots of migrants and poorly-educated people-is also seen as an obstacle. SPL assume that the tenants will not be able to adapt their behaviour to the specific needs of an energy efficient home (e.g., ventilation habits). From the perception of SPL, tenants value visible investment such as balconies, new flooring or new kitchens, rather than "invisible" energy efficiency measures.

They literally heat through out the window. They turn on the heat to the highest level and if it is getting too hot, they just open the window. Why should I isolate my façade, when they just open the window and all the energy is wasted (IP 13: 75)

Finally, existing funding schemes to boost energy efficiency investment do not seem to have any effect on individual decisions (funding/political scheme). 
We have neither used the "Modernisierungsumlage" nor have increased the rent ( ... ) we have a 5 Euro rental market and in the end it was safer to avoid tenant movements. For me, it is difficult to increase the rent due to energy renovations in this market because the people move 2,3 houses further. In the end every Euro you pay counts (IP 15: 42-44)

The explorative qualitative research undertaken illustrates the complex and multi-layered nature of the decision-making processes of SPL. It identifies various factors that influence the decisions made by SPL about renovations. How relevant these are, and whether they hinder or promote the landlords' decision to renovate, was not the task of the problem-centred interviews. In addition, due to the small sample size, the results cannot be assumed to be representative of all SPL. The following quantitative research evaluates the identified determinants in terms of their quantitative influence on the decision to renovate.

\section{Results from the Quantitative Research}

\subsection{Measures and Model Set Up}

Participants completed the questionnaire, which included the measures shown in Table 1. Before the questionnaire was finalised, pre-tests (five interviews with SPL using "think aloud" and "probing" methods) and reviews by senior academics and SPL were conducted [57,58].

In addition to the 14 identified determinants, socio-demographics (SPL age, level of education, children, years of ownership, distance between rental property and home address) and building-related variables (type of ownership, form of acquisition, usage and building age) were collected and added to the model. Cronbach's alpha was calculated to examine scale reliability and internal consistency. Model assumptions (multicollinearity, heteroskedasticity, etc.) were tested and the model set up was adapted where necessary. For the statistical analysis, a hierarchical OLS regression was performed. In a "hierarchical regression, IVs (independent variables) enter the equation in an order specified by the researcher. Each IV is assessed in terms of what it adds to the equation at its own point of entry" [50]. Consequently, five models were created, building on each other to represent the four dimensions of the explanatory model and the socio-demographic data and building-related variables.

Table 1. Measurement of determinants.

\begin{tabular}{|c|c|c|c|}
\hline Dimension & Determinant & Item & Source \\
\hline 党 & $\begin{array}{c}\text { Environmental } \\
\text { awareness }\end{array}$ & $\begin{array}{l}\text { - If things continue on their present course, we will soon } \\
\text { experience a major ecological catastrophe } \\
\text { - The so-called "ecological crisis" facing humankind has } \\
\text { been greatly exaggerated } \\
\text { - The balance of nature is strong enough to cope with the } \\
\text { impacts of modern industrial nations } \\
\text { - } \quad \text { Humans are severely abusing the environment } \\
\text { The earth has plenty of natural resources if we just learn } \\
\text { how to develop them }\end{array}$ & $\begin{array}{l}\text { [59], selection by } \\
\text { Stern et al. [60] }\end{array}$ \\
\hline 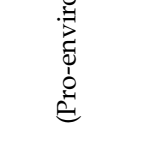 & Personal norm & $\begin{array}{l}\text { I feel morally obligated to invest in energy efficiency, } \\
\text { regardless of what others are doing } \\
\text { I feel guilty if I don't invest in improving energy } \\
\text { efficiency in my home }\end{array}$ & adapted from [61] \\
\hline
\end{tabular}


Table 1. Cont.

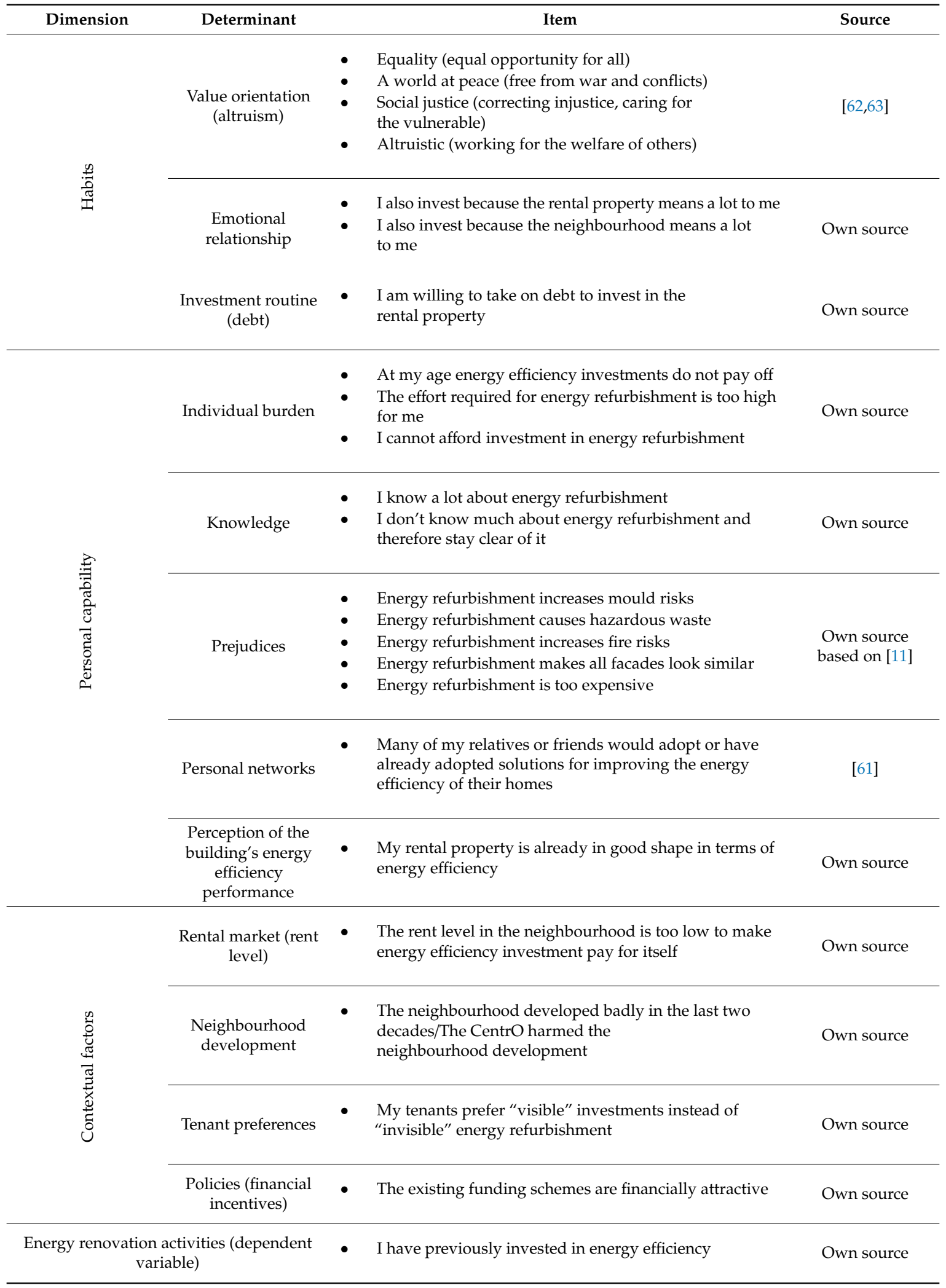

Note: For each determinant/item, respondents were asked to indicate their agreement with the statements on a 5 point Likert-type scale from $1=$ "totally disagree" to $5=$ "totally agree". Value orientation (altruism) is an exception. Here, respondents were asked to rate the importance of each item as a "guiding principle" in their lives on an 8 point Likert-type scale from $0=$ "not important" to $7=$ "extremely important". 


\subsection{Results}

\subsubsection{Sample Description}

The sample consists of 351 SPL. Due to missing values, only 190 complete cases exist, which are included in the regression model. A total of $51 \%$ own an apartment building and $49 \%$ are part of a homeowner community. SPL are above the national average in terms of their age: almost $40 \%$ of our respondents are over 65 years old compared to a national average of $25 \%$ (based on residents aged 18 and over). For the majority of SPL, letting is a secondary source of income. Overall, about $55 \%$ of the participants own fewer than six rented apartments and $80 \%$ fewer than 16 . SPL have a high level of education, with $38 \%$ of the participants having a university degree (the national average is only $16 \%$ ). Around one third of the participants inherited or were gifted their rental property. Around $30 \%$ of the participants live in the neighbourhood (postal code) in which the rental property is located; over $70 \%$ live less than $25 \mathrm{~km}$ from their rental property. In terms of both socio-demographic data and property ownership characteristics, the sample is thus comparable with representative national data [64].

\subsubsection{Regression Model}

Table 2 shows the descriptive statistics, correlations and reliability statistics. Table 3 illustrates the hierarchical regression model.

The four decision dimensions identified from the qualitative research, as well as the socio-demographic and building-specific variables surveyed, contribute to a significant improvement in the model quality. This confirms what can already be assumed from the interview phase, that the decision-making processes of SPL are very complex and can only be explained by considering various determinants and variables.

However, the four dimensions contribute very differently to the model quality. The explanatory power of the "(pro-environmental) attitude", "habits" and "external factors" is evident, but their impact is low. It is in fact the "individual capabilities" dimension, as well as the socio-demographic and building-specific variables, that determine the model quality.

The complex regression model no. 5 results from adding the various determinants and variables. It contains the determinants of the decision model developed in the qualitative research, as well as various owner-specific and building-specific variables. With an adjusted $R^{2}=0.49$, it has a high variance explanation. It makes clear that knowledge about energy renovation measures, personal networks and the perception of the building's energy efficiency performance are crucial drivers for investment. Prejudice, on the other hand, is a barrier.

In addition, it is evident that SPL who live in the rental property themselves are more willing to carry out energy renovation measures. Similarly, owners of apartment buildings renovate significantly more frequently than owners in a HOA (homeowner association). Having children tends to have a negative effect on investment levels. As expected, residential buildings built after 1978, i.e., after the first Heat Insulation Ordinance came into force, are less frequently refurbished. There is no statistical correlation for all the older building age classes. Neither the individual age, the form of acquisition, the educational level nor the duration of ownership have a statistically significant influence.

In the regression model, three interactions (value (altruism) and emotional relationship; neighbourhood development and rental market (rent level); and personal norms and tenant preferences) were also identified from the determinants, which by themselves have no main effect but only a conditional effect.

In addition to the determinants that have a statistically significant impact, there are also factors of interest for which the assumed influence could not be confirmed. For example, "financial incentives" as a policy for fostering energy renovation has no significant influence on investment decisions. Marketing campaigns for energy renovation always highlight ecological added value, but the model shows that existing environmental awareness and personal norms have no relevant influence on renovation decisions. 
Table 2. Means, standard deviations (SD), Cronbach's alpha and pairwise correlation coefficients.

\begin{tabular}{|c|c|c|c|c|c|c|c|c|c|c|c|c|c|c|c|c|c|c|c|c|}
\hline & \multirow[b]{2}{*}{ Determinants } & \multirow[b]{2}{*}{$\begin{array}{l}\text { Number } \\
\text { of Items }\end{array}$} & \multirow[b]{2}{*}{$\begin{array}{l}\text { Mean } \\
\text { (M) }\end{array}$} & \multirow[b]{2}{*}{$\begin{array}{c}\text { Standard } \\
\text { Deviation (SD) }\end{array}$} & \multirow[b]{2}{*}{$\begin{array}{l}\text { Cronbach's } \\
\text { Alpha }\end{array}$} & \multicolumn{15}{|c|}{ Correlation (Spearman, Two-Sided) } \\
\hline & & & & & & (1) & (2) & (3) & (4) & (5) & (6) & (7) & (8) & (9) & (10) & (11) & (12) & (13) & (14) & (15) \\
\hline$(1)$ & $\begin{array}{l}\text { Environmental } \\
\text { awareness }\end{array}$ & 5 & 3.62 & 0.64 & 0.67 & 1 & $\begin{array}{c}0.17 \\
* *\end{array}$ & $\underset{* *}{0.26}$ & -0.01 & 0.02 & -0.03 & 0.03 & -0.07 & $\begin{array}{l}-0.12 \\
*\end{array}$ & -0.03 & 0.04 & 0.03 & 0.00 & 0.03 & 0.00 \\
\hline$(2)$ & Personal norms & 2 & 2.27 & 0.95 & 0.73 & & 1 & $\underset{* *}{0.26}$ & $\underset{* *}{0.15}$ & 0.09 & $\underset{*}{-0.14}$ & 0.02 & -0.38 & 0.11 & $\underset{* * *}{0.23}$ & -0.03 & -0.27 & -0.25 & 0.34 & $0.17^{* *}$ \\
\hline (3) & Values (altruism) & 4 & 5.61 & 1.05 & 0.76 & & & 1 & $\begin{array}{c}0.22 \\
* * * \\
\end{array}$ & -0.06 & 0.04 & -0.00 & $\underset{*}{-0.16}$ & 0.04 & 0.12 & 0.09 & -0.08 & -0.06 & $\begin{array}{c}0.14 \\
*\end{array}$ & 0.06 \\
\hline (4) & Identity & 2 & 3 & 1.1 & 0.74 & & & & 1 & 0.07 & -0.08 & $\underset{*}{0.12}$ & -0.08 & $\underset{* *}{0.23}$ & 0.09 & -0.01 & -0.23 & -0.05 & 0.24 & 0.28 \\
\hline (5) & Investment routine & 1 & 2.34 & 1.22 & & & & & & 1 & $\underset{* *}{-0.17}$ & 0.19 & 0.03 & 0.01 & 0.09 & -0.04 & -0.08 & -0.09 & 0.06 & 0.06 \\
\hline (6) & Individual burden & 3 & 2.99 & 0.97 & 0.73 & & & & & & 1 & $\begin{array}{l}-0.41 \\
* * * \\
\end{array}$ & $\underset{* * *}{0.21}$ & -0.27 & $-0.21^{* *}$ & * -0.04 & 0.27 & 0.05 & $\begin{array}{c}-0.14 \\
*\end{array}$ & $\underset{* * *}{-0.29}$ \\
\hline (7) & Knowledge & 2 & 3.36 & 0.97 & 0.71 & & & & & & & 1 & $\underset{* *}{0.17}$ & 0.27 & $0.15^{* *}$ & 0.09 & 0.01 & $\underset{*}{0.12}$ & -0.07 & 0.35 \\
\hline$(8)$ & Prejudice & 5 & 3.23 & 0.87 & 0.80 & & & & & & & & 1 & -0.08 & $\begin{array}{l}-0.14 \\
* \\
\end{array}$ & 0.08 & $\begin{array}{c}0.37 \\
* * * \\
\end{array}$ & $\begin{array}{l}0.27 \\
* * * \\
\end{array}$ & $\begin{array}{c}-0.28 \\
* * * \\
\end{array}$ & $\underset{* *}{-0.20}$ \\
\hline (9) & $\begin{array}{l}\text { Energy efficiency } \\
\text { self-perception }\end{array}$ & 1 & 3.08 & 0.97 & & & & & & & & & & 1 & $\underset{*}{0.13}$ & 0.06 & $\begin{array}{c}-0.22 \\
* * * \\
\end{array}$ & 0.08 & $\begin{array}{c}0.13 \\
*\end{array}$ & 0.42 \\
\hline (10) & Personal networks & 1 & 2.65 & 0.97 & & & & & & & & & & & 1 & $-0.12^{*}$ & -0.25 & $\stackrel{-0.13}{*}$ & $\begin{array}{c}0.13 \\
*\end{array}$ & $\begin{array}{l}0.33 \\
* * *\end{array}$ \\
\hline (11) & $\begin{array}{c}\text { Neighbourhood } \\
\text { development }\end{array}$ & 2 & 4.1 & 0.88 & 0.66 & & & & & & & & & & & 1 & $0.18^{* *}$ & 0.04 & $\begin{array}{c}-0.12 \\
* \\
\end{array}$ & 0.04 \\
\hline (12) & $\begin{array}{l}\text { Rental market (rent } \\
\text { level) }\end{array}$ & 1 & 3.87 & 0.99 & & & & & & & & & & & & & 1 & $\begin{array}{l}0.28 \\
* * * * \\
\end{array}$ & -0.36 & $\underset{* * * *}{-0.23}$ \\
\hline (13) & Tenant preferences & 1 & 3.75 & 0.96 & & & & & & & & & & & & & & 1 & -0.15 & 0.00 \\
\hline (14) & Policies (incentives) & 1 & 2.59 & 0.94 & & & & & & & & & & & & & & & 1 & 0.09 \\
\hline (15) & Retrofit activities & 1 & 2.64 & 1.21 & & & & & & & & & & & & & & & & 1 \\
\hline
\end{tabular}


Table 3. Hierarchical regression model.

\begin{tabular}{|c|c|c|c|c|c|c|}
\hline & & (1) & (2) & (3) & (4) & (5) \\
\hline \multirow{4}{*}{ 总 } & Environmental awareness & 0.05 & -0.03 & 0.04 & 0.03 & -0.07 \\
\hline & & $(0.13)$ & $(0.14)$ & $(0.12)$ & $(0.12)$ & $(0.12)$ \\
\hline & Personal norms & 0.19 ** & 0.14 & -0.01 & -0.04 & -0.02 \\
\hline & & $(0.09)$ & $(0.09)$ & $(0.08)$ & $(0.08)$ & $(0.08)$ \\
\hline \multirow{6}{*}{$\begin{array}{l}\frac{0}{0} \\
\frac{0}{0} \\
\frac{0}{1}\end{array}$} & Values (altruism) & & 0.11 & 0.03 & 0.06 & 0.09 \\
\hline & & & $(0.09)$ & $(0.08)$ & $(0.08)$ & $(0.07)$ \\
\hline & Emotional relationship & & $0.28^{* * *}$ & $0.19^{* * *}$ & $0.16^{* *}$ & 0.06 \\
\hline & & & $(0.08)$ & $(0.07)$ & $(0.07)$ & $(0.07)$ \\
\hline & Investment routine & & 0.02 & -0.03 & -0.05 & -0.05 \\
\hline & & & $(0.07)$ & $(0.06)$ & $(0.06)$ & $(0.05)$ \\
\hline \multirow{10}{*}{ 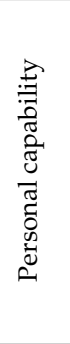 } & Individual burden & & & -0.06 & -0.08 & -0.12 \\
\hline & & & & $(0.09)$ & $(0.09)$ & $(0.09)$ \\
\hline & Knowledge & & & $0.29^{* * *}$ & $0.32 * * *$ & $0.30^{* * *}$ \\
\hline & & & & $(0.09)$ & $(0.09)$ & $(0.09)$ \\
\hline & Perjudices & & & $-0.17^{*}$ & $-0.16^{*}$ & $-0.21^{* *}$ \\
\hline & & & & $(0.09)$ & $(0.09)$ & $(0.09)$ \\
\hline & Perception of buildings energy & & & $0.39 * * *$ & $0.37^{* * *}$ & $0.40^{* * *}$ \\
\hline & efficiency perfomance & & & $(0.08)$ & $(0.08)$ & $(0.08)$ \\
\hline & Personal networks & & & $0.32 * * *$ & $0.30 * * *$ & $0.27 * * *$ \\
\hline & & & & $(0.08)$ & $(0.08)$ & $(0.08)$ \\
\hline \multirow{8}{*}{ 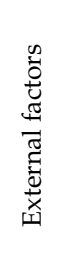 } & Neighbourhood development & & & & -0.02 & 0.01 \\
\hline & & & & & $(0.09)$ & $(0.08)$ \\
\hline & Rental market (rent level) & & & & -0.01 & -0.04 \\
\hline & & & & & $(0.09)$ & $(0.08)$ \\
\hline & Tenant preferences & & & & -0.04 & -0.01 \\
\hline & & & & & $(0.08)$ & $(0.08)$ \\
\hline & Policies (incentives) & & & & -0.01 & -0.04 \\
\hline & & & & & $(0.09)$ & $(0.08)$ \\
\hline \multirow{10}{*}{ 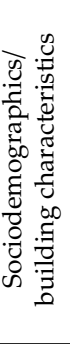 } & Usage (owner-occupied) & & & & & $0.37 *$ \\
\hline & & & & & & $(0.2)$ \\
\hline & Type of ownership (builindg owner) & & & & & $0.44^{* *}$ \\
\hline & & & & & & $(0.19)$ \\
\hline & Childnen & & & & & $-0.36^{* *}$ \\
\hline & & & & & & $(0.17)$ \\
\hline & Distance between home and property & & & & & $0.002^{* * *}$ \\
\hline & address & & & & & $(0.001)$ \\
\hline & Building age (younger than 1978) & & & & & $-0.94^{* * *}$ \\
\hline & & & & & & $(0.34)$ \\
\hline \multirow{14}{*}{ 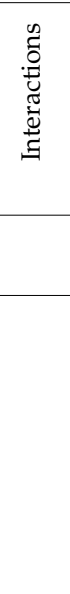 } & Interaction1 (rent X neighbourhood) & & & & $0.21 * *$ & $0.21 * *$ \\
\hline & Tntantion & & & & $(0.09)$ & $(0.08)$ \\
\hline & Interaction 2 (value $\mathrm{X}$ emotional & & 0.08 & $0.15^{* *}$ & $0.16^{* *}$ & $0.19^{* * *}$ \\
\hline & relationship) & & $(0.09)$ & $(0.07)$ & $(0.07)$ & $(0.07)$ \\
\hline & $\begin{array}{c}\text { Interaction } 3 \text { (Personal norm } \mathrm{X} \text { tenant } \\
\text { preferences) }\end{array}$ & & & & $0.20 * *$ & $0.26^{* * *}$ \\
\hline & Constante & 0.06 & 0.06 & -0.04 & -0.04 & 0.005 \\
\hline & & $(0.09)$ & $(0.09)$ & $(0.08)$ & $(0.08)$ & $(0.07)$ \\
\hline & AIC & 604.4 & 595.6 & 532.2 & 532.4 & 505.3 \\
\hline & Observations & 190 & 190 & 190 & 190 & 190 \\
\hline & $\mathrm{R} 2$ & 0.03 & 0.11 & 0.4 & 0.43 & 0.58 \\
\hline & Adjusted R2 & 0.02 & 0.08 & 0.36 & 0.38 & 0.49 \\
\hline & Residual Std. Error & 1.17 & 1.13 & 0.95 & 0.93 & 0.84 \\
\hline & Kesidual sta. Error & $(\mathrm{df}=187)$ & $(\mathrm{df}=183)$ & $(\mathrm{df}=178)$ & $(\mathrm{df}=172)$ & $(\mathrm{df}=158)$ \\
\hline & F Statistic & $\begin{array}{c}2.73 * \\
(\mathrm{df}=2 \\
187)\end{array}$ & $\begin{array}{c}3.80 * * * \\
(\mathrm{df}=6 \\
183)\end{array}$ & $\begin{array}{c}10.60 * * * \\
(\mathrm{df}=11 \\
178)\end{array}$ & $\begin{array}{c}7.70 * * * \\
(\mathrm{df}=17 \\
172)\end{array}$ & $\begin{array}{c}6.90^{* * *} \\
(\mathrm{df}=31 ; 158)\end{array}$ \\
\hline
\end{tabular}

Note: ${ }^{*} p<0.1 ;{ }^{* *} p<0.05 ;{ }^{* *} p<0.01$, standard error in brackets, Model 1 to 5 hierarchical OLS-Regression, sozio-economics and building-related variables only displayed if statistically significant.

\section{Key Findings and Discussion}

The findings from the qualitative and quantitative research shed light on the decision-making processes of SPL. They help to understand what deters SPL from making energy efficiency investments 
and provide some indication of how to adjust policies to better fit the specific needs of the target group. Four main findings with recommendations can be identified.

\subsection{Better Understand and Target the Investment Behaviour}

The empirical studies clearly show that the investment behaviour of SPL differs from the behaviour advocated by the current political regime. Even though the investment routine was not statistically significant in the model, it became clear that SPL try to avoid taking on debt. A total of $63 \%$ of the participants of this survey and as many as $90 \%$ of SPL in a nationwide survey only finance investments from savings and avoid taking out loans [64]. As SPL are not even tempted by the current low interest rates, this points to the recommendation that funding programmes should offer grants instead of subsidised loans. In the model, "funding schemes" have no statistical significance and the descriptive statistics show that funding is not financially attractive. This is another strong indication of the need for a paradigm shift in public funding from subsidised loans to grants (which do not currently exist for SPL). The typical investment routine of stepwise investments, which follow a saving/investment pattern in order to keep effort and capital costs under control, should also be acknowledged in the funding schemes. Currently, comprehensive renovations towards $\mathrm{KfW}$ standards attract higher funding rates of up to $27.5 \%$, while single measures only receive between $7.5 \%$ and $15 \%$. Therefore, funding rates should be based on a property owner's commitment to achieve an energy efficiency standard by implementing single measures according to a renovation "roadmap" within 5 to 10 years. This means that SPL would receive higher financial support for investing incrementally in renovations towards KfW standards.

SPL rarely demonstrate strategic investment planning; they tend to invest on an ad-hoc basis to meet specific needs. In addition, they are conservative, status-quo oriented and less motivated by maximising returns than by long-term, stress-free tenancies. The so-called "Modernisierungsumlage" has become a synonym for gentrification and the pursuit by landlords of financial returns. However, the analysis shows that SPL are more altruistic than expected. A total of $90 \%$ prefer longstanding tenancies to high returns and almost $60 \%$ do not increase their rents during tenancies. Both these characteristics are in line with other German studies, as previously outlined [30] and point to the need to adapt the 'Modernisierungsumlage'. Reforming the policy, for example by coupling the transferable costs with the benefit to the tenant (lower heating costs), could also increase the social acceptance of energy renovations.

Homeowner communities are a special case, since any investment is based on a group dynamic and not an individual decision-making process. The regression model illustrates that communities of owners invest less in energy efficiency than "normal" property owners. One of the main reasons is complex residential property law (WEG). This requires a high proportion of the property owners to commit to implementing energy efficient measures $-75 \%$ of all property owners have to agree-and demands the application of highly developed communication skills by housing managers to unite the different investment logic, opinions, expectations etc., of the property owners. To improve this situation, we propose that approval rates should be lowered to $50 \%$ (in line with non-energy measures (e.g., painting a wall)) and property managers should be well-trained and better paid [65]. This could include the establishment of funding schemes to support property managers and the creation of new schemes targeting the role of property managers.

\subsection{Improve Knowledge Through Exchange and Networking}

The quantitative analysis in particular shows that knowledge and personal networks play an important role in energy efficiency investment decisions. Knowledge helps SPL to be aware of technological options and to assess both the risks and opportunities, as well as reducing their reservations in terms of the effort and complexity of energy renovation measures.

Despite various information campaigns, it is overwhelmingly clear that a multitude of prejudices (mould risk, financial, ecological, aesthetic, structural) have a negative influence on investment activity. 
Previous strategies to change the attitudes of SPL and increase their investment in energy efficiency renovations by providing knowledge through information campaigns and energy consulting have largely failed. Networks and word-of-mouth recommendations seem to offer a more promising solution. Letting is only a sideline for SPL and, due to their limited time budgets, decisions are made heuristically. Positive experiences from personal networks or recommendations from tradesmen have a positive effect on investment, as their assessment is perceived as credible and trustworthy. However, the qualitative research in particular makes it clear that many SPL do not network with other property owners and feel like "lone fighters". A communication strategy must, therefore, focus on bringing SPL together so they can exchange experiences and know-how face-to-face. An area-based approach, as in this case study, would seem to be promising because activities could be tailored to the specific needs of SPL. It could also create a community feeling and strengthen sense of identity within the neighbourhood. Neighbourhood walking tours, opportunities for property owners to meet together or open-home events could be a good starting point for establishing networks among SPL [66]. Demonstration projects could also be an important tool for making energy efficiency tangible. The varying level of qualifications of tradesmen and energy consultants has also hampered investment in energy efficiency, which suggests that better education and certification of energy efficiency measures would also be a positive move.

\subsection{Support and Promote a Sense of Responsibility}

SPL, at least in the area of our research, seem to act in a more welfare-oriented and responsible manner than their public reputation would suggest. However, their sense of responsibility does not tend to encompass ecological responsibility for tackling climate change. Despite their levels of environmental awareness, that goal seems abstract and intangible. The analysis highlights the fact that environmental awareness and moral obligation do not automatically translate into pro-environmental behaviour: a value-action gap exists [56]. Consequently, campaigns and information focusing on the ecological benefits of energy renovation do not seem to be effective.

Instead, the sense of social and geographic responsibility that exists amongst SPL could be harnessed to promote investment. Many SPL live, or used to live, in the same neighbourhood, city or surrounding area in which their rental property is located. In the case study, approximately $75 \%$ of all SPL live within $25 \mathrm{~km}$ of their rental property. This not only creates an emotional relationship with the neighbourhood, but also an awareness of the neighbourhood's development. The same also applies to the rental property itself, as many such properties have been handed down from generation to generation. The neighbourhood and the rental property are, therefore, linked to memories and social relationships, from which a sense of responsibility can develop. If the landlord lives in the apartment building or in the neighbourhood, investment made in the rental property will also benefit the landlord. There is also the sense of responsibility towards the tenants: long-term tenancies are few and far between, but such stable and hassle-free tenancies are sought after. This multidimensional sense of responsibility, of course, varies across the owner group. The challenge is: a) to identify those landlords who have the potential to serve as change agents and door-openers to others; and b) to awaken the disproportionate willingness of this subgroup to invest in energy efficient refurbishment measures.

\subsection{Greater Focus on Local Framework Conditions}

Neighbourhoods are characterised by different local conditions. It was not possible to conclusively identify from the available literature or the empirical work presented whether, and in which direction, neighbourhood development, the housing market and the tenant/resident structure influence investments in energy-saving renovation measures. This signals a clear need for further research. While the qualitative research identified neighbourhood development and low rental levels as central barriers to investment, the regression model showed no significant impact. It is obvious, however, that the framework conditions in Oberhausen are different from those in Berlin, Munich or Düsseldorf, and that this results in different return expectations, investment risks and investment motives. For example, 
energy-related refurbishment measures can ensure leaseability in a low-demand housing market such as Oberhausen. The same measure could, however, contribute to energy-related gentrification in Berlin. Consequently, it would be useful to promote research projects on the influence of local conditions on refurbishment decisions. If this research were to find a link between different regional and local conditions and levels of energy efficiency investment, the current practice of distributing funding with no regard for geographical differences would have to be reconsidered. Funding rates and their allocation could be differentiated on a geographical basis.

\section{Conclusions}

The decarbonisation of residential building stock is an important component for the success of the German Energiewende. Despite some progress having been made, there has been increasing reluctance in recent years to implement energy-saving renovation measures and a decline in investment activity has been observed. Moreover, refurbishment rates differ according to property owner type. The backlog in renovations in properties owned by small private landlords is particularly high, which raises the question of how to foster energy efficiency investments.

To answer this question, the paper analyses the investment decision-making processes of SPL using a mixed-method approach for a case study in Oberhausen, in the Ruhr area of Germany. Problem-centred interviews and a postal survey provide insights into the decision-making processes of the target group. The analysis makes both a theoretical and a political contribution to the debate on energy renovation. The development of an integrated explanatory model is a central added-value aspect of the work. On the one hand, it identifies determinants that promote and inhibit the success of SPL. It broadens the perspective on the refurbishment backlog of small private landlords beyond the usual economic debate, as it identifies many determinants that cannot be explained by economic theory. It thus encourages further research to verify the findings and to better understand the decision-making process. On the other hand, the model illustrates the complexity of the decision-making processes and highlights the fact that one-dimensional political solutions have little potential for success. This insight is the main political added-value aspect of the work. The results suggest that policies following the "one size fits all" principle are insufficient. Instead, comprehensive knowledge of the different owner groups and their decision-making logic is needed. Consequently, experimental settings and political will is crucial for testing and implementing the changes proposed in this research study on both small and large scales. This should ultimately lead to alterations to the policy framework to meet the specific requirements of the target group and boost energy renovation.

Author Contributions: S.M. conceptualized and wrote the study as part of his PhD. R.S. and A.B. supported the study with regard to its methodological foundations and the discussion and recommendations based on the key findings. They also proofread the manuscript. All authors have read and agreed to the published version of the manuscript.

Funding: This research was funded by Ministerium für Kultur und Wissenschaft des Landes Nordrhein-Westfalen as part of the project "Energieeffizienz im Quartier-Clever versorgen, umbauen, aktivieren" (Energy Efficiency at District Level-Intelligent Supply, Modify, Activate".

Acknowledgments: This work was conducted within above mentioned project, funded by the Ministerium für Kultur und Wissenschaft des Landes Nordrhein-Westfalen. Moreover, the authors would like to thank all interviewees and all participants of the survey, the city of Oberhausen for their cooperation and the anonymous reviewers.

Conflicts of Interest: The authors declare no conflict of interest.

\section{References}

1. Rockström, J.; Steffen, W.; Noone, K.; Persson, Å.; Chapin, F.S.; Lambin, E.F.; Lenton, T.M.; Scheffer, M.; Folke, C.; Schellnhuber, H.J.; et al. A safe operating space for humanity. Nature 2009, 461, 472-475. [CrossRef]

2. IPCC. Global Warming of $1.5^{\circ} \mathrm{C}$. Summary for Policymakers; IPCC special report on the impacts of global warming of $1.5^{\circ} \mathrm{C}$ above pre-industrial levels and global greenhouse gas emission pathways, in the context 
of strengthening the global response to the threat of climate change, sustainable development, and the efforts of eradicate poverty; Intergovernmental Panel on Climate Change: Geneva, Switzerland, 2018.

3. BMWi; BMU. Energiekonzept für eine Umweltschonende, Zuverlässige und Bezahlbare Energieversorgung vom 28.09.2010; Bundesministerium für Wirtschaft und Energie für die Bundesregierung: Berlin, Germany, 2010; p. 40.

4. BMUB. Klimaschutzplan 2050. In Klimapolitische Grundsätze und Ziele der Bundesregierung; Bundesministerium für Umwelt, Naturschutz und nukleare Sicherheit: Berlin, Germany, 2016.

5. Cischinsky, D.H.; Diefenbach, D.N. Datenerhebung Wohngebäudebestand 2016. In Datenerhebung zu den Energetischen Merkmalen und Modernisierungsraten im Deutschen und Hessischen Wohngebäudebestand; Institut Wohnen und Umwelt (IWU): Darmstadt, Germany, 2018; p. 179.

6. Diefenbach, N.; Cischinsky, H.; Rodenfels, M.; Clausnitzer, K.-D. Datenbasis Gebäudebestand: Datenerhebung zur Energetischen Qualität und zu den Modernisierungstrends im Deutschen Wohngebäudebestand; Institut Wohnen und Umwelt (IWU), Bremer Energie Institut (BEI): Darmstadt, Germany, 2010.

7. BBSR. Struktur der Bestandsinvestitionen 2014. In Investitionstätigkeit in den Wohnungs- und Nichtwohnungsbeständen; Bundesinstitut für Bau-, Stadt- und Raumforschung: Bonn, Germany, 2016.

8. Diefenbach, N.; Stein, B.; Loga, T.; Rodenfels, M.; Gabriel, J. Monitoring der KfW-Programme Energieeffizient Sanieren und Energieeffizient Bauen 2015; Institut für Wohnen und Umwelt GmbH (IWU): Darmstadt, Germany; Fraunhofer IFAM: Bremen, Germany, 2016.

9. Ambrose, A.R. Improving energy efficiency in private rented housing: Why don't landlords act? Indoor Built Environ. 2015, 24, 913-924. [CrossRef]

10. Hope, A.J.; Booth, A. Attitudes and behaviours of private sector landlords towards the energy efficiency of tenanted homes. Energy Policy 2014, 75, 369-378. [CrossRef]

11. Friege, J. Increasing homeowners' insulation activity in Germany: An empirically grounded agent-based model analysis. Energy Build. 2016, 128, 756-771. [CrossRef]

12. Friege, J.; Holtz, G.; Chappin, É.J.L. Exploring Homeowners' Insulation Activity. J. Artif. Soc. Soc. Simul. 2016, 19, 4. [CrossRef]

13. Galvin, R. Why German homeowners are reluctant to retrofit. Build. Res. Inf. 2014, 42, 398-408. [CrossRef]

14. Stieß, I.; Dunkelberg, E. Objectives, barriers and occasions for energy efficient refurbishment by private homeowners. J. Clean. Prod. 2013, 48, 250-259. [CrossRef]

15. Vom Hofe, M. Energetische Sanierung von Einfamilienhäusern: Drei Essays über Motive, Entscheidungsprozesse und Aktivierungsmöglichkeiten im Kontext von Privateigentum; TU Dortmund: Dortmund, Germany, 2018.

16. Bartiaux, F.; Gram-Hanssen, K.; Fonseca, P.; Ozolina, L.; Christensen, T.H. A practice-theory approach to homeowners' energy retrofits in four European areas. Build. Res. Inf. 2014, 42, 525-538. [CrossRef]

17. Gram-Hanssen, K. Retro fitting owner-occupied housing: Remember the people. Build. Res. Inf. 2014, 42, 393-397. [CrossRef]

18. Wilson, C.; Pettifor, H.; Chryssochoidis, G. Quantitative modelling of why and how homeowners decide to renovate energy efficiently. Appl. Energy 2018, 212, 1333-1344. [CrossRef]

19. Wilson, C.; Crane, L.; Chryssochoidis, G. Why do homeowners renovate energy efficiently? Contrasting perspectives and implications for policy. Energy Res. Soc. Sci. 2015, 7, 12-22. [CrossRef]

20. Im, J.; Seo, Y.; Cetin, K.S.; Singh, J. Energy efficiency in U.S. residential rental housing: Adoption rates and impact on rent. Appl. Energy 2017, 205, 1021-1033. [CrossRef]

21. Palm, J.; Reindl, K. Understanding barriers to energy-efficiency renovations of multifamily dwellings. Energy Effic. 2017, 11, 53-65. [CrossRef]

22. März, S. Beyond economics-Understanding the decision-making of German small private landlords in terms of energy efficiency investment. Energy Effic. 2018, 11, 1721-1743. [CrossRef]

23. Weiß, J.; Bierwirth, A.; Knöfel, J.; März, S.; Kaselofsky, J.; Friege, J. Entscheidungskontexte bei der Energetischen Sanierung. Ergebnisse aus dem Projekt Perspektiven der Bürgerbeteiligung an der Energiewende unter Berücksichtigung von Verteilungsfragen; Institut für ökologische Wirtschaftsforschung: Berlin, Germany; Wuppertal Institut für Klima, Umwelt, Energie: Wuppertal, Germany, 2018.

24. Tashakkori, A.M.; Teddlie, C.B. Mixed Methodology: Combining Qualitative and Quantitative Approaches; Applied Social Research: Thousand Oaks, CA, USA, 1998; ISBN 978-0-7619-0071-9.

25. BMWi. Energy Efficiency Strategy for Buildings. In Methods for Achieving a Virtually Climate-Neutral Building Stock; Federal Ministry for Economic Affairs and Energy: Berlin, Germany, 2015. 
26. Schüring, A. German Strategy for Energy-Efficient-Buildings \& $\mathrm{CO}_{2}$-Rehabilitation Programme; Federal Ministry for Economic Affairs and Energy: Berlin, Germany, 2014.

27. Rosenow, J.; Galvin, R. Evaluating the evaluations: Evidence from energy efficiency programmes in Germany and the UK. Energy Build. 2013, 62, 450-458. [CrossRef]

28. IEA. Energy Policies of IEA Countries. Germany 2013 Review; International Energy Agency: Paris, France, 2013.

29. Michelsen, C.; Rosenschon, S.; Schulz, C. Small might be beautiful, but bigger performs better: Scale economies in "green" refurbishments of apartment housing. Energy Econ. 2015, 50, 240-250. [CrossRef]

30. Henger, R.M.; Voigtländer, M. Einflussfaktoren auf die Rentabilität energetischer Sanierungen bei Mietobjekten. Inst. Dtsch. Wirtsch. Köln IW-Trends Vierteljahr. Empir. Wirtsch. Inst. Dtsch. Wirtsch. Köln 2011, 38, 49-66.

31. Renz, I.; Hacke, U. Einflussfaktoren auf die Sanierung im deutschen Wohngebäudebestand. Ergebnisse einer qualitativen Studie zu Sanierungsanreizen und -hemmnissen privater und institutioneller Eigentümer; Institut Wohnen und Umwelt (IWU): Darmstadt, Germany, 2016.

32. Kaßler, M. Scheitert die Energiewende im Gebäudebereich an den Wohneigentümergemeinschaften; Dachverband Deutscher Immobilienverwalter e.V.: Berlin, Germany, 2015.

33. DECC. Final Stage Impact Assessment for the Private Rented Sector Regulations; Department of Energy and Climate Change: London, UK, 2015.

34. Broberg, T.; Egüez, A. Blame it on the owner-Ownership and energy performance of multi-dwelling buildings. Energy Econ. 2018, 72, 108-119. [CrossRef]

35. Carroll, J.; Aravena, C.; Denny, E. Low energy efficiency in rental properties: Asymmetric information or low willingness-to-pay? Energy Policy 2016, 96, 617-629. [CrossRef]

36. IEA. Mind the Gap: Quantifying Principal-Agent Problems in Energy Efficiency; OECD/IEA: Paris, France, 2007; ISBN 978-92-64-03884-4.

37. Guerra-Santin, O.; Romero Herrera, N.; Cuerda, E.; Keyson, D. Mixed methods approach to determine occupants' behaviour-Analysis of two case studies. Energy Build. 2016, 130, 546-566. [CrossRef]

38. Riazi, M.; Emami, A. Residential satisfaction in affordable housing: A mixed method study. Cities 2018, 82, 1-9. [CrossRef]

39. Ding, L. Applying gamifications to asynchronous online discussions: A mixed methods study. Comput. Hum. Behav. 2019, 91, 1-11. [CrossRef]

40. Mikalef, P.; Boura, M.; Lekakos, G.; Krogstie, J. Big data analytics and firm performance: Findings from a mixed-method approach. J. Bus. Res. 2019, 98, 261-276. [CrossRef]

41. Lopez-Fernandez, O.; Molina-Azorin, J.F. The use of mixed methods research in the field of behavioural sciences. Qual. Quant. 2011, 45, 1459. [CrossRef]

42. Johnson, R.B.; Turner, L.S. Data collection strategies in mixed methods research. In Handbook of Mixed Methods in Social \& Behavioral Research; Tashakkori, A., Teddlie, C., Eds.; SAGE Publications: London, UK, 2003; ISBN 978-0-7619-2073-1.

43. Johnson, R.B.; Onwuegbuzie, A.J.; Turner, L.A. Toward a Definition of Mixed Methods Research. J. Mix. Methods Res. 2007, 1, 112-133. [CrossRef]

44. Morse, J.M. Approaches to qualitative-quantitative methodological triangulation. Nurs. Res. 1991, 40, 120-123. [CrossRef]

45. Mayring, P. Qualitative Inhaltsanalyse: Grundlagen und Techniken; Beltz Pädagogik; 11, Aktualisierte und Überarb. Aufl; Beltz: Weinheim, Germany, 2010; ISBN 978-3-407-25533-4.

46. Strauss, A.L. Grundlagen qualitativer Sozialforschung: Datenanalyse und Theoriebildung in der empirischen soziologischen Forschung; Übergänge: Texte und Studien zu Handlung, Sprache und Lebenswelt; Fink: München, Germany, 1991; ISBN 978-3-7705-2656-7.

47. Galvin, R. How many interviews are enough? Do qualitative interviews in building energy consumption research produce reliable knowledge? J. Build. Eng. 2015, 1, 2-12. [CrossRef]

48. Patton, M.Q. Qualitative Evaluation and Research Methods, 2nd ed.; SAGE Publications, Inc.: Newbury Park, CA, USA, 1990; ISBN 978-0-8039-3779-6.

49. Dillman, D.A.; Smyth, J.D.; Christian, L.M. Internet, Mail, and Mixed-Mode Surveys: The Tailored Design Method; 3. Auflage; John Wiley \& Sons: Hoboken, NJ, USA, 2008; ISBN 978-0-471-69868-5.

50. Tabachnick, B.G.; Fidell, L.S. Using Multivariate Statistics, 5th ed.; Pearson: Boston, MA, USA, 2005; ISBN 978-0-205-46525-5. 
51. März, S.; Bierwirth, A.; Hauptstock, D. Rethink the target: Drivers, barriers and path dependencies for a low-carbon-transition in shrinking cities; the case of Oberhausen. In Rethink, Renew, Restart: Proceedings of the ECEEE 2013 Summer Study, Belambra Les Criques, Toulon/Hyères, France, 3-8 June 2013; Lindström, T., Ed.; Europ. Council for an Energy Efficient Economy: Stockholm, Sweden, 2013; pp. 783-793.

52. Blume, J. Oberhausen und der Strukturwandel. Bauwelt 1996, 87, 2556-2561.

53. Dellwig, M.; Richter, E.-J. Wirtschaft im Wandel. Oberhausen 1960 bis 2010. In Oberhausen in Wirtschaftswunder und Strukturwandel; Dellwig, M., Ed.; Aschendorff: Münster, Germany, 2012; pp. 53-140. ISBN 978-3-402-12959-3.

54. Pagel, C. Höchste Verschuldung in Deutschland: Oberhausen—Die Stadt, die von innen stirbt—Die Wahl in Nordrhein-Westfalen. 2012. Available online: https://www.focus.de/politik/deutschland/nrw-wahl/hoechsteverschuldung-in-deutschland-oberhausen-die-stadt-die-von-innen-stirbt_aid_749397.html (accessed on 24 February 2020).

55. Stern, P. New Environmental Theories: Toward a Coherent Theory of Environmentally Significant Behavior. J. Soc. Issues 2000, 56, 407-424. [CrossRef]

56. Kollmuss, A.; Agyeman, J. Mind the Gap: Why do people act environmentally and what are the barriers to pro-environmental behavior? Environ. Educ. Res. 2002, 8, 239-260. [CrossRef]

57. Porst, R. Fragebogen. Ein Arbeitsbuch; Studienskripten zur Soziologie; 4. Auflage; Springer: Wiesbaden, Germany, 2014.

58. Weichhold, M. Handbuch Methoden der Empirischen Sozialforschung; Baur, N., Blasius, J., Eds.; Springer: Wiesbaden, Germany, 2014; pp. 299-304. ISBN 978-3-531-17809-7.

59. Dunlap, R.E.; Van Liere, K.D.; Mertig, A.G.; Jones, R.E. New Trends in Measuring Environmental Attitudes: Measuring Endorsement of the New Ecological Paradigm: A Revised NEP Scale. J. Soc. Issues 2000, 56, 425-442. [CrossRef]

60. Stern, P.; Dietz, T.; Abel, T.; Guagnano, G.; Kalof, L. A Value-Belief-Norm Theory of Support for Social Movements: The Case of Environmentalism. Hum. Ecol. Rev. 1999, 6, 81-97.

61. Fornara, F.; Pattitoni, P.; Mura, M.; Strazzera, E. Predicting intention to improve household energy efficiency: The role of value-belief-norm theory, normative and informational influence, and specific attitude. J. Environ. Psychol. 2016, 45, 1-10. [CrossRef]

62. Schwartz, S.H. Universals in the Content and Structure of Values: Theoretical Advances and Empirical Tests in 20 Countries. In Advances in Experimental Social Psychology; Zanna, M.P., Ed.; Academic Press: Cambridge, MA, USA, 1992; Volume 25, pp. 1-65.

63. Groot, J.I.M.; de Steg, L. Value Orientations to Explain Beliefs Related to Environmental Significant Behavior How to Measure Egoistic, Altruistic, and Biospheric Value Orientations. Environ. Behav. 2008, 40, 330-354. [CrossRef]

64. Cischinsky, H.; Kirchner, J.; Vaché, M.; Rodenfels, M.; Nuss, G. Privateigentümer von Mietwohnungen in Mehrfamilienhäusern; BBST-Online-Publikation; Institut Wohnen und Umwelt (IWU): Bonn, Germany, 2015.

65. Bretzmann, A.; Bäumer, T.; Huber, S. The Role of Participation and Communication for Energy Efficient Refurbishment. Econ. Environ. Stud. 2017, 17, 675-691. [CrossRef]

66. Berry, S.; Sharp, A.; Hamilton, J.; Killip, G. Inspiring low-energy retrofits: The influence of open home events. Build. Res. Inf. 2014, 42, 422-433. [CrossRef]

(C) 2020 by the authors. Licensee MDPI, Basel, Switzerland. This article is an open access article distributed under the terms and conditions of the Creative Commons Attribution (CC BY) license (http://creativecommons.org/licenses/by/4.0/). 